\title{
SOIL MOVEMENT FOR COMMON CHISEL PLOW SHARES IN EGYPT
}

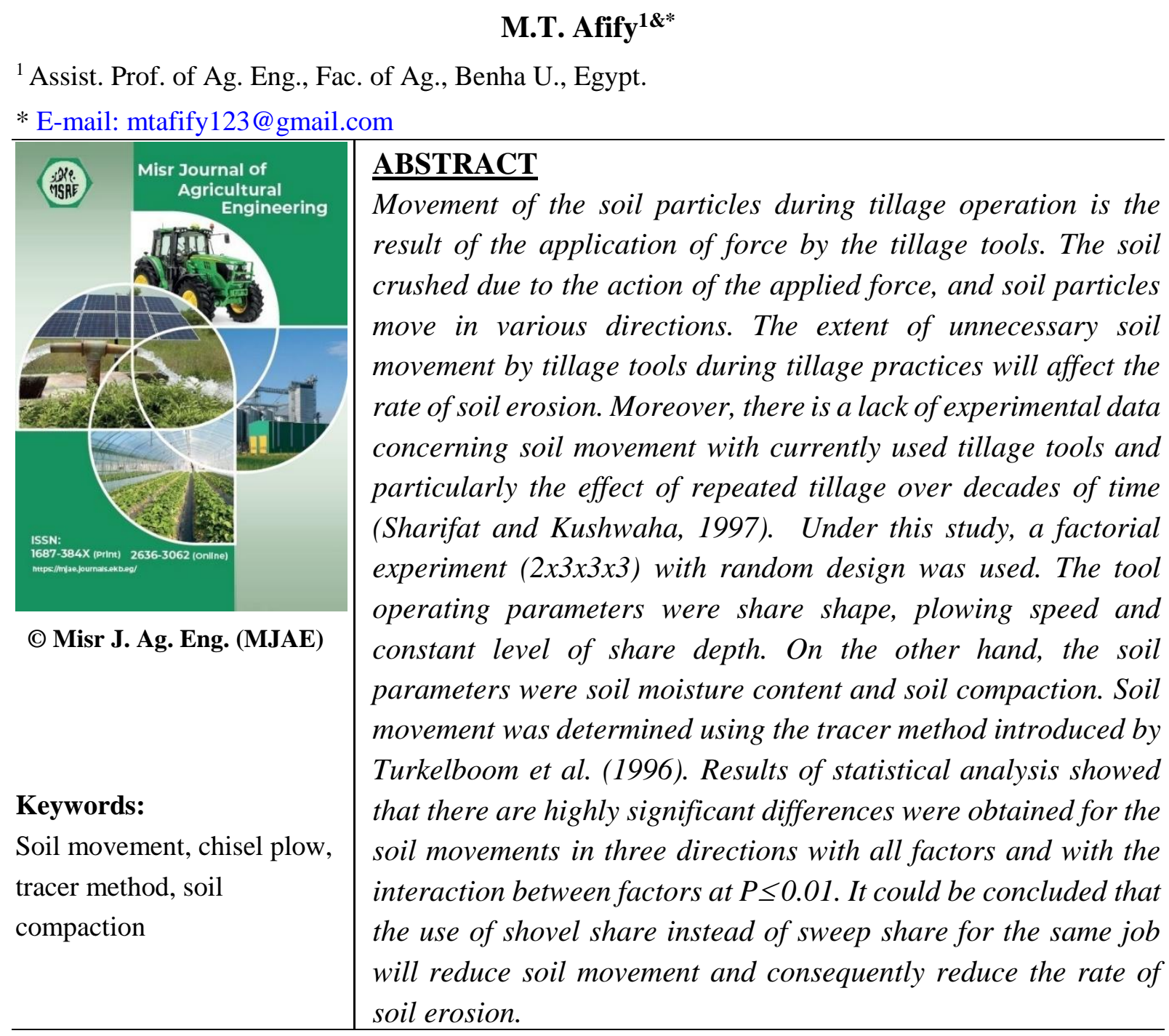

\section{INTRODUCTION}

$\mathrm{T}$ illage is the most fundamental and essential farm operation. It is necessary to provide the optimum environment for a good seedbed by shearing, loosening, and moving the soil. It is also considered as the most energy consuming work in farming. There is appreciable movement of soil during tillage, of which much is not only unneeded but also contributes to soil erosion. Moreover, in recent years, there has been a growing belief that the use of tillage implements is a major contributor to accelerating soil erosion, which adversely affects crop productivity by reducing the availability of water, nutrients, and restricting rooting depth by depleting the top soil (Pimentel, 1993). llison (1947) stated that the soil erosion process consists of two principle sequential events. These are detachment and transportation. In the first event, soil particles are detached from their moorings in the soil mass and made available for transport. In the second event, detached soil particles are transported. The first event that contributes to the erosion process is not only unavoidable, but is necessary to provide desirable soil structure, water infiltration, and incorporation of fertilizers. Accompanying of 
this event, soil is ready for the second event of erosion, the transportation of soil with the tillage tools (Sharifat and Kushwaha (1997). In their studies on tillage erosion rates, Turkelboom et al. (1996) used three complementary methods for measuring soil movement in tillage. These were the tracer method, the trench method, and the step method. The result of experiments by using the above methods showed that the tracer method and the step method gave very similar results. The step method followed a linear trend, while the tracer method showed a slightly exponential relationship. The trench method was supposed to provide more accurate results since in this method the transported soil was collected directly. Studies by Chase (1942) and Eidet (1974) showed that increasing the rake angle of the plow share increased the amount of lateral soil displacement. Dowell et al. (1988) found that the ridge height and lateral distance of soil particles that thrown by a sweep increased with travel speed. Hanna et al. (1993b) in a study of changes in soil micro-topography by tillage with a sweep concluded that higher speed and larger rake angle in sweep resulted in more movement of soil to build higher ridges. In another study, Hanna et al. (1993a) compared the soil flow path on a sweep with the Goryachkin theory (Goryachkin, 1968). The conclusions of this study supported the Goryachkin model in identifying rake angle and excluding speed and depth as factors influencing soil flow path. Söhne (1960) studied soil movement perpendicular to the travel direction with a wide tool in high-speed plowing and observed that the magnitude of lateral soil displacement increased with the lateral directional angle at the end of the moldboard plow. Lobb and Kachanoski (1997) conducted some experiments to determine soil movement by tillage. Plots of soil in different fields were labeled by Cesium-137 and chloride as tracers and the concentration of the tracers was measured after tillage operations. Distribution of the tracers was used to describe soil movement by tillage. They concluded that tillage translocation could be explained by slope gradient alone, confirming that slope gradient is the main factor driving tillage translocation. However, slope curvature also significantly affected tillage translocation and should be used for future modeling. Sibbesen and Anderson (1985) introduced a simple mathematical model for predicting soil movement in horizontal direction by repeated tillage with one or more tillage tools in alternating directions. The model used the solution of a diffusion equation to describe the development with time of a concentration gradient of a substance. They proposed a simple mathematical model to predict the movement of soil. The model is suitable for use in situations where the same cultivation practices are repeated many times in alternating directions. Therefore, the objective of this paper is to study the effect of soil conditions and tool parameters on the soil movement as a contributing factor to soil erosion using two common shares of chisel plow in Egypt.

\section{MATERIALS AND METHODS}

\subsection{Experimental procedure:}

To achieve the objective of this study, a $2 \times 3 \times 3 \times 3$ factorial experiment with random design was used. Fifty-four tests with three replicates were conducted in the soil bin at the Department of Agric. \& Bioresource Engineering, University of Saskatchewan, Canada. The following parameters were studied.

\subsection{Tool operation parameters:}

- Share shape (Figure 1). Two share shapes were used. These were 250-mm sweep share and 100-mm double point shovel share. 

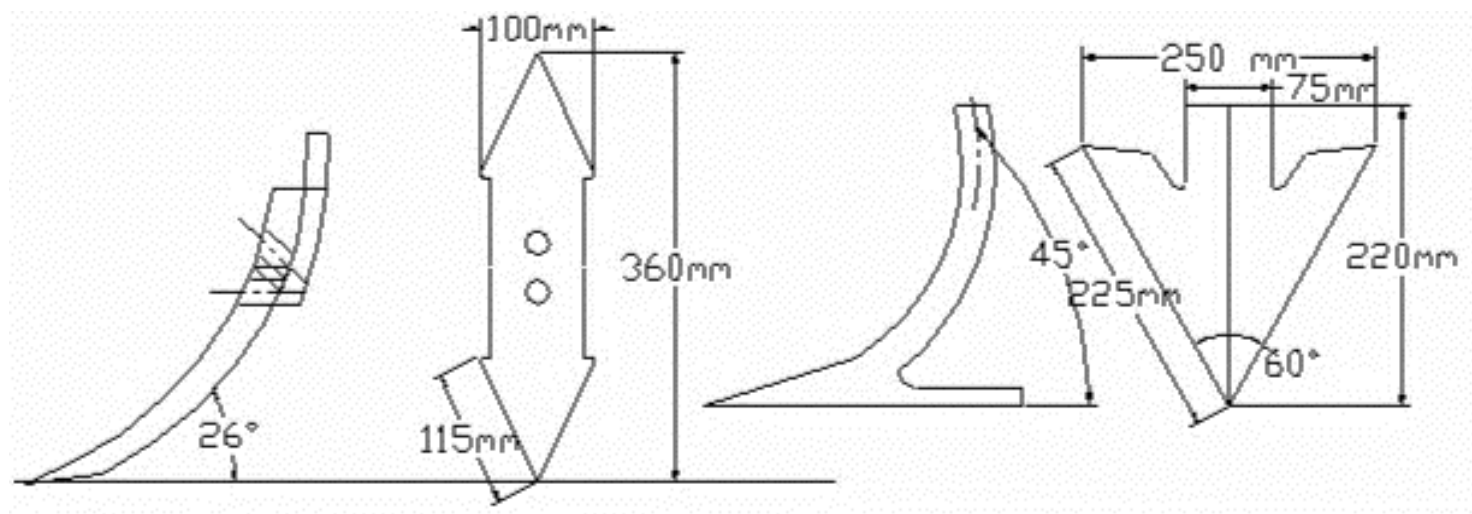

Figure (1): Double points shovel and sweep shares.

- Three levels of operation speeds of $5 \mathrm{~km} / \mathrm{h}, 6.5 \mathrm{~km} / \mathrm{h}$ and $8 \mathrm{~km} / \mathrm{h}$.

- Depth of operation was measured to be $90 \mathrm{~mm}$.

\subsection{Soil conditions:}

- Three levels of soil moisture contents of low (10-11\%), medium (13-14\%) and high (16-18\%).

- Three soil compaction levels of low (200-220 kPa), medium (300-324 kPa) and high (400$425 \mathrm{kPa})$.

\subsection{Measurements:}

- Soil moisture content was determined according to the standard methodology (ASTM, 1991).

- Soil compaction levels were determined by Cone Index measurements with a Cone Penetrometer. Six readings of penetration resistance were taken randomly along the soil bin before each test to obtain "Average Cone Index" of the soil. Soil penetration resistances were measured at $100 \mathrm{~mm}$ depth. A standard of 30 degree Cone Penetrometer S 313.2 (ASAE, 1990) of a $130 \mathrm{~mm}^{2}$ by $12.83 \mathrm{~mm}$ diameter with $9.53 \mathrm{~mm}$ diameter shaft was used to determine soil resistance to penetration.

- Soil movement was determined using the tracer method introduced by Turkelboom et al. (1996). In this method a tracer is placed in the soil and after running the tillage tool, the position or concentration of the tracers are measured. New positions of the tracers are correlated to the soil movement. The plastic blocks $(15 \times 15 \times 11 \mathrm{~mm})$ with density nearly equal to that of soil $\left(1.2 \mathrm{~g} / \mathrm{cm}^{3}\right)$ in a vertical slot prepared perpendicular to the direction of travel of tillage tool. The total width of the blocks layer was $315 \mathrm{~mm}$ and a total of 126 blocks were placed in 6 layers to a depth of $90 \mathrm{~mm}$. Block positions were specified by different colors for rows and numbers for columns as shown in Figure 2. The x-y-z references of every point in the soil bin were provided by an instrumentation system (Figure 3) developed to measure the final position of the blocks after each run. Some modifications were made in the soil bin, so that the device can be used in any place along the soil bin to measure the $x-y-z$ references of any point in the soil bin. The device had a pointer, which was movable in $x-y-z$ directions. Three potentiometers were used to measure the movements of the pointer in the $x-$ $y-z$ directions. A portable identification device with digital readouts was designed to enter the color code and the number of each block manually. The pointer of the measuring system was positioned on the center of each block. By pushing the digitizing button, the $\mathrm{x}-\mathrm{y}-\mathrm{z}$ references of the block along with its specifications were printed out and simultaneously recorded in the computer. 
123456789101112131415161718192021

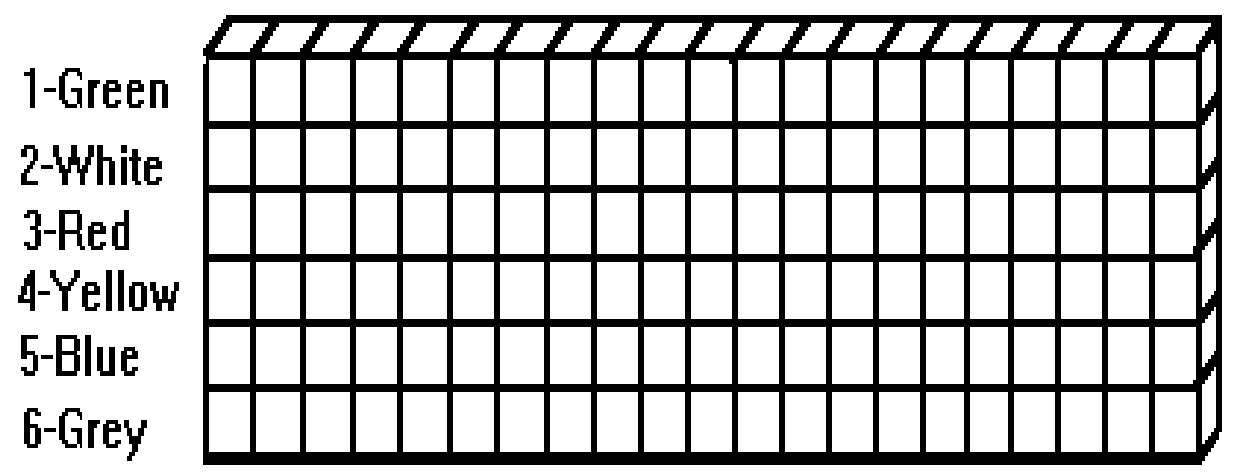

Figure (2): Block configuration (After Sharifat and Kushwaha, 1997).

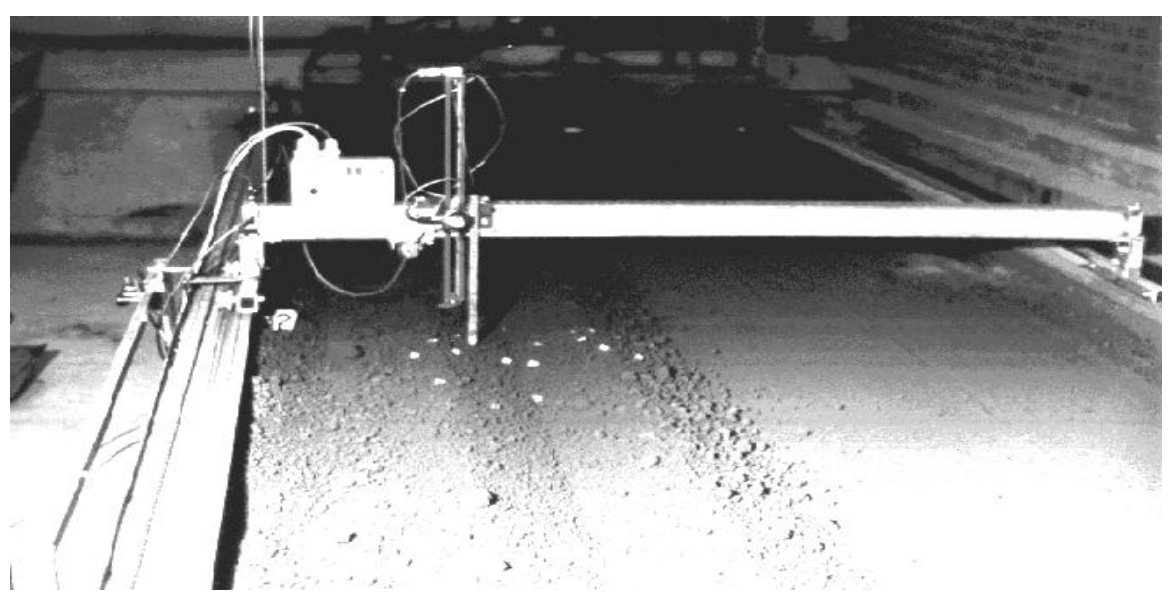

Figure (3): The reference (x-y-z) measuring system (After Sharifat and Kushwaha, 1997).

\section{RESULTS AND DISCUSSION}

\subsection{Effect of the tool shape on the soil movement in three directions}

Figures 4 shows the average distance movement of plastic blocks in three directions with the depth of the block layer for two shares at high levels of soil moisture and soil compaction and under $8 \mathrm{~km} / \mathrm{h}$ forward speed. It is cleared that, the block's movement in the three directions was inversely proportional to the depth of the block layer for the two shares. Blocks had largest and lowest movement at the soil surface and bottom layer, respectively. Although the lowest block layer was the first one to come in contact with the share surface, however the undisturbed soil in front of it acted like a cushion preventing movement of blocks. The upper layers faced partially disturbed soil under the influence of disturbance in lower layers, resulting in less cushioning property in front of the blocks. This resulted in a larger movement of blocks located in upper layers. The average forward, lateral, and vertical movements of plastic blocks in the three directions for the sweep share increased by $36 \%, 24 \%$, and $29 \%$ and by $40 \%, 57 \%$, and $68 \%$ for the frontal area for the sweep compared with that for the shovel share, respectively. In general, the most important movement for both shares was forward movement. Therefore, the forward movement of plastic blocks was inversely proportional to their distance from the center line of the tool in the direction of travel as shown in Figure 5. An increase in lateral distance from the center line of the tool resulted in less forward movement of the plastic blocks for both shares. Those blocks located on the center line moved considerably greater distance. 


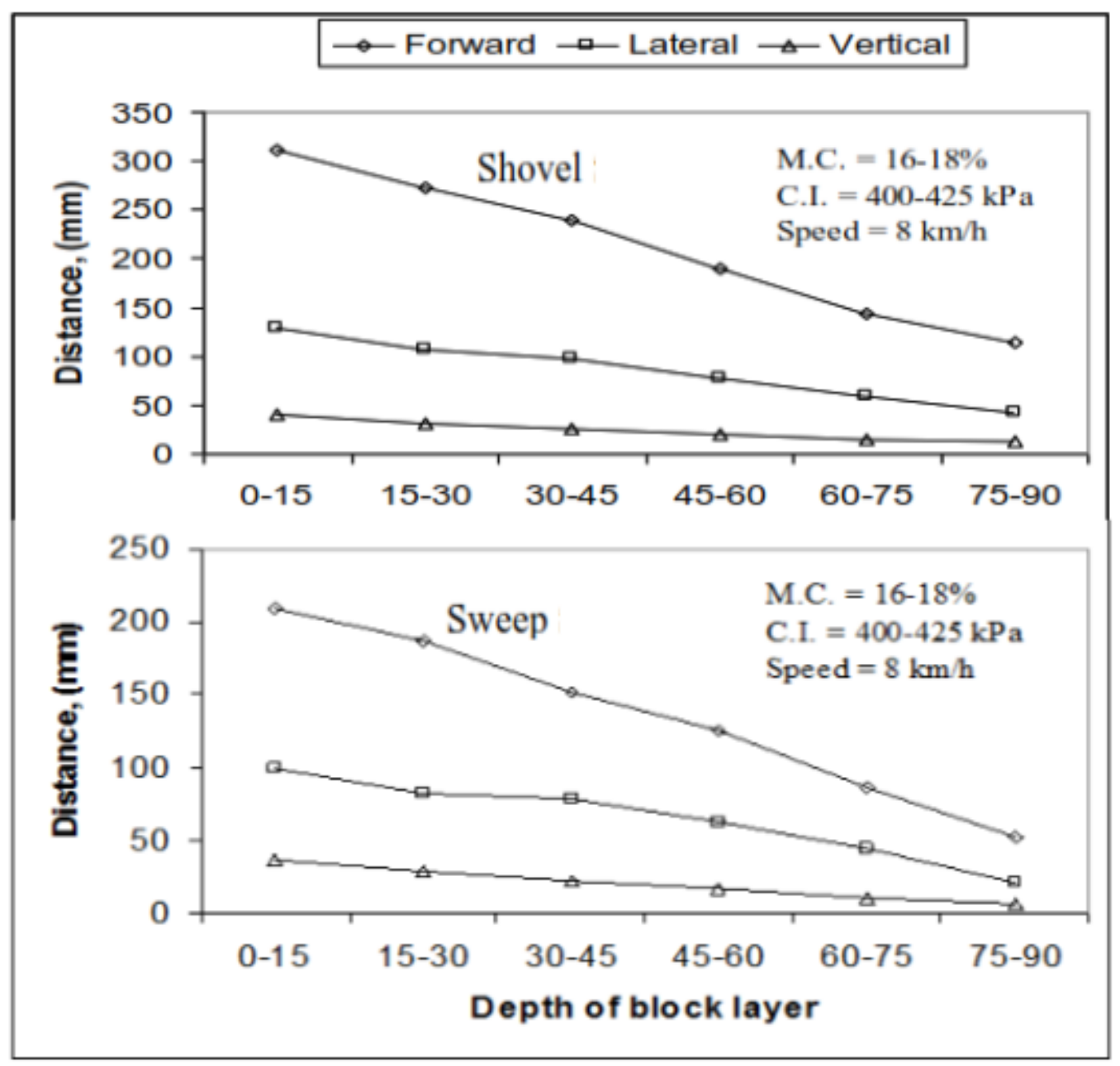

Figure (4): The average distance of plastic blocks movements in three directions at different depths of block layer using the shovel and sweep shares.

The difference in the movement of plastic blocks by the two shares was due to the difference in their flow path over the tool surface. Motion of the particles during tillage is the result of two motions, a motion with the tillage tool and a motion relative to the tillage tool. A block with a larger flow path over the surface of the tillage tool needs more time to travel along its flow path, and consequently will be transferred over a larger distance. This result might be due to their impact with the tool shank and consequently causes the blocks to travel further.

\subsection{Effect of the speed of operation on the soil movement in three directions}

Figures 6 is representing the average distance of plastic blocks movements in three directions in relation to operation speed at high levels of soil moisture and soil compaction for the sweep and the shovel shares, respectively. The movements of the plastic blocks in three directions increased as the speed of operation increased for two shares. This is due to the soil particles were transferred over a large distance by the tillage tools when the speed of operation increased. The forward movement of the plastic blocks with the sweep increased by $22 \%$ and $28 \%$ compared with that for shovel when the travel speed increased from 5 to $8 \mathrm{~km} / \mathrm{h}$, respectively. The increase of operating speed from 5 to $8 \mathrm{~km} / \mathrm{h}$ was followed with an increase in the lateral and vertical movements of plastic blocks with percentages of $33 \%$ and $19 \%$ for shovel share 
and $31 \%$ and $14 \%$ for sweep share, respectively. In a comparison between two shares, the sweep share resulted in the highest values of plastic blocks movements in three directions compared with that for the shovel share at different levels of operation speeds. The percentages increases were $23 \%, 25 \%$, and $21 \%$ for forward, lateral, and vertical movements, respectively.

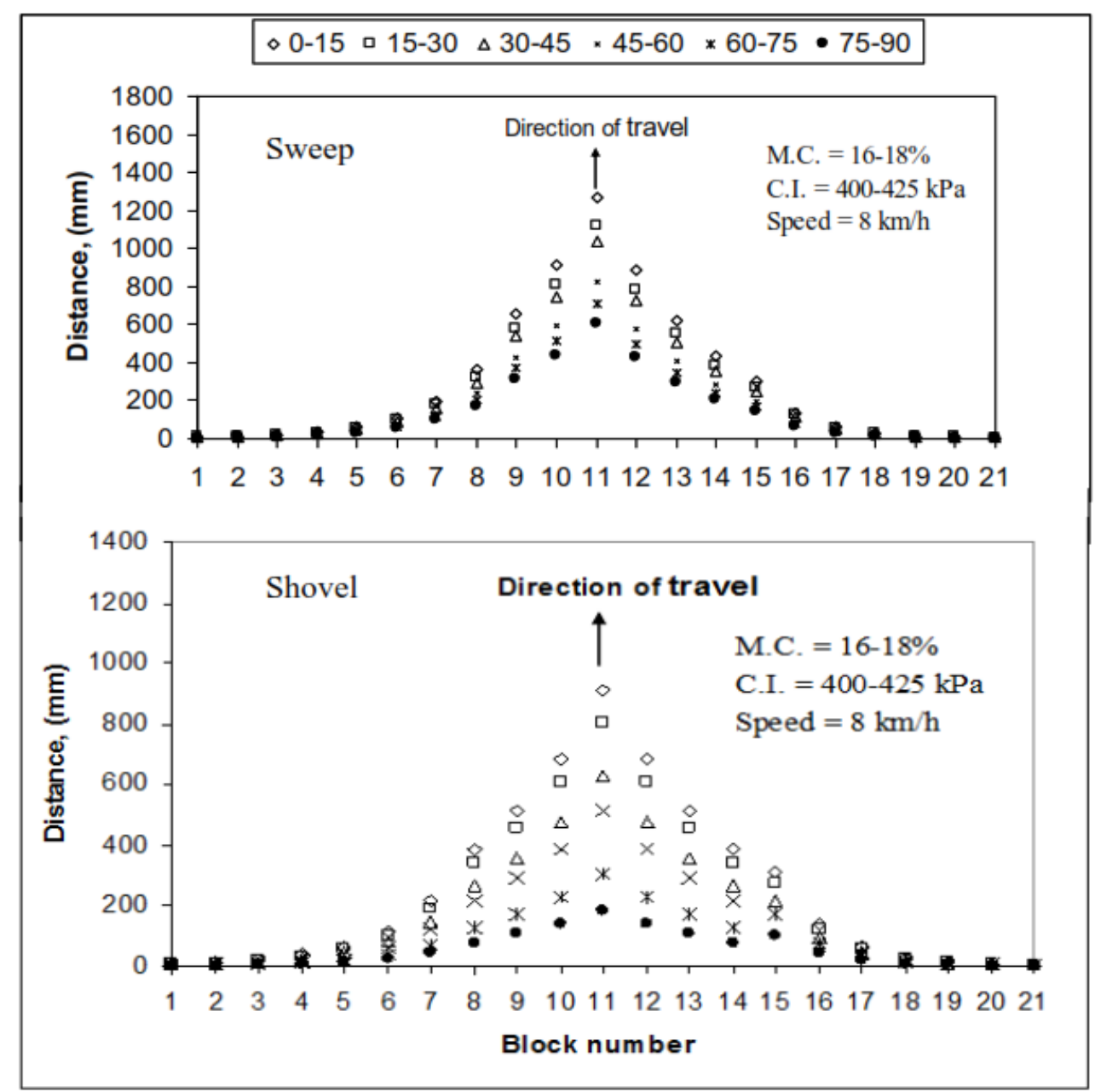

Figure (5): Forward movement of plastic blocks at different depths of block layer by the sweep and shovel shares.

\subsection{Effect of the soil moisture content on the soil movement in three directions}

Figure 7 represents the effect of the soil moisture content on the average distance of plastic blocks movements in three directions for the two shares at high level of soil compaction and at $5 \mathrm{~km} / \mathrm{h}$ speed. The movements of plastic blocks in three directions increased as the soil moisture content increased for both shares. Increasing the soil moisture content from low level to high level resulted in $15 \%$ and $21 \%$ increase in the forward movement of the plastic blocks for the sweep and shovel shares, respectively. The forward movement of plastic blocks for sweep increased by $28 \%, 31 \%$ and $34 \%$ compared with that for shovel at different levels of soil moisture content, respectively. These results may have been attributed to the following reasons: 1) the increase in adhesion of soil to the surface of tillage tool, which would have decreased the relative velocity of the particles flowing over the tillage tool surface, thus causing the variations in soil movement. 2) the increase in the frontal area of the sweep share compared with that for the shovel share. Results of the lateral and vertical movements of plastic blocks for both shares 
showed similar trends as that with the forward movement at various levels of soil moisture content except for the lateral movement increased by $28 \%$ and $36 \%$ when the soil moisture increased from low level to high level for the sweep and shovel shares, respectively. While, the vertical movement is increased by $33 \%$ and $29 \%$, respectively.

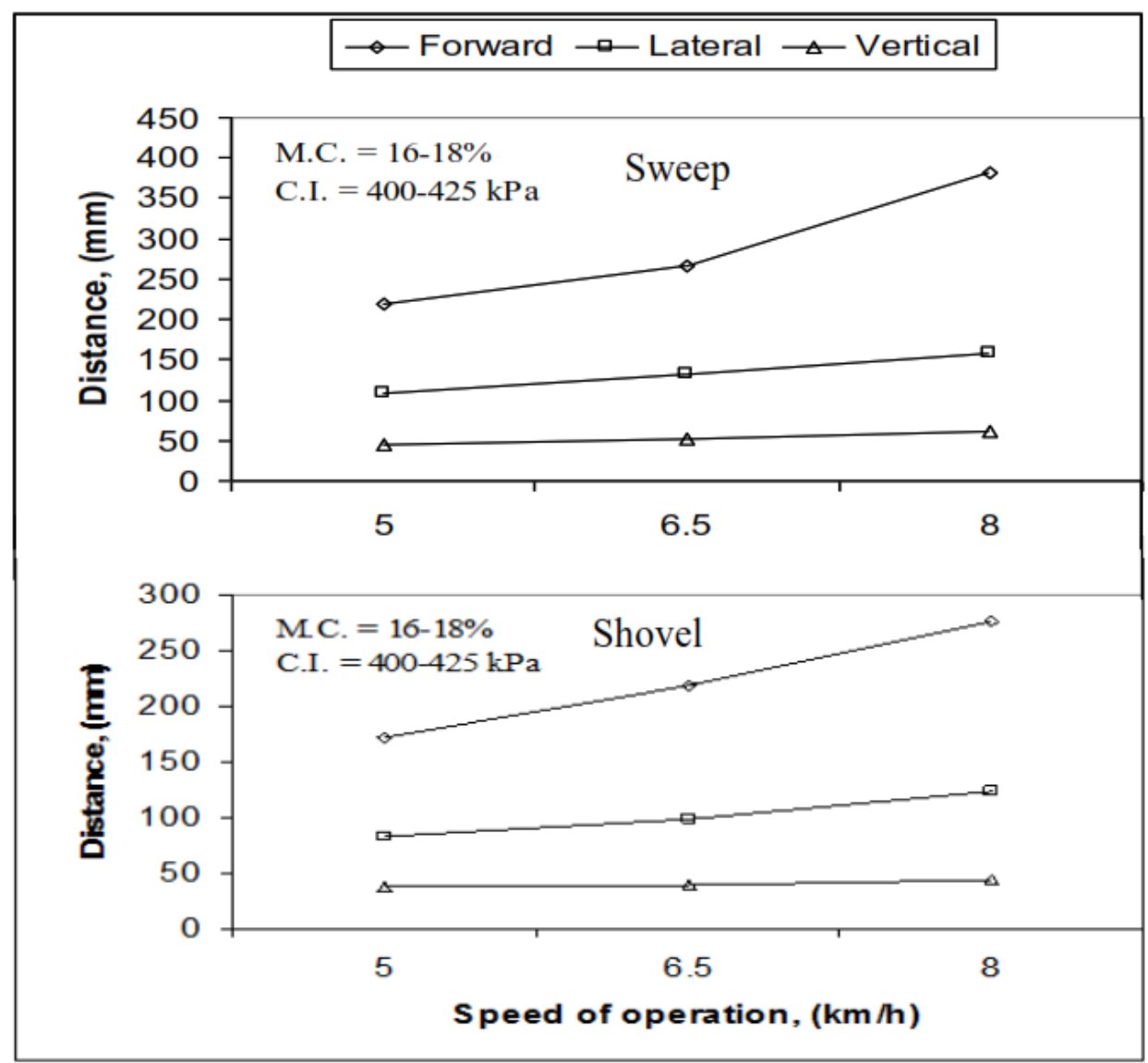

Figure (6): The average distance of plastic blocks movements in three directions at different speeds of operation using the sweep and shovel shares.

\subsection{Effect of the soil compaction on the soil movement in three directions}

Figure 8 shows the effect of the soil compaction levels on the average distance of plastic blocks movements in three directions for the two shares at high level of soil moisture content ranged from $16 \%$ to $18 \%$ and at $8 \mathrm{~km} / \mathrm{h}$ speed. The movements of plastic blocks in three directions decreased as the level of soil compaction increased for the two shares. This is due to the increase of soil shear strength, resulting in less soil movement on a volumetric basis. The forward movement of plastic blocks decreased by $16 \%$ and $9 \%$ as the level of soil compaction increased from low level to high level for the sweep and shovel shares, respectively. Results of the lateral and vertical movements of plastic blocks for both shares showed similar trends as that with the forward movement at various levels of soil compaction. The use of shovel share was accompanied with lower values of the average distance of plastic blocks movements comparing with sweep one. These values were 232, 89, and $28 \mathrm{~mm}$ for shovel share and 354, 144, and $39 \mathrm{~mm}$ for sweep one. These results may be attributed to the increase of the frontal area, the cutting width, and the rake angle of the sweep share compared with that for the shovel share. 


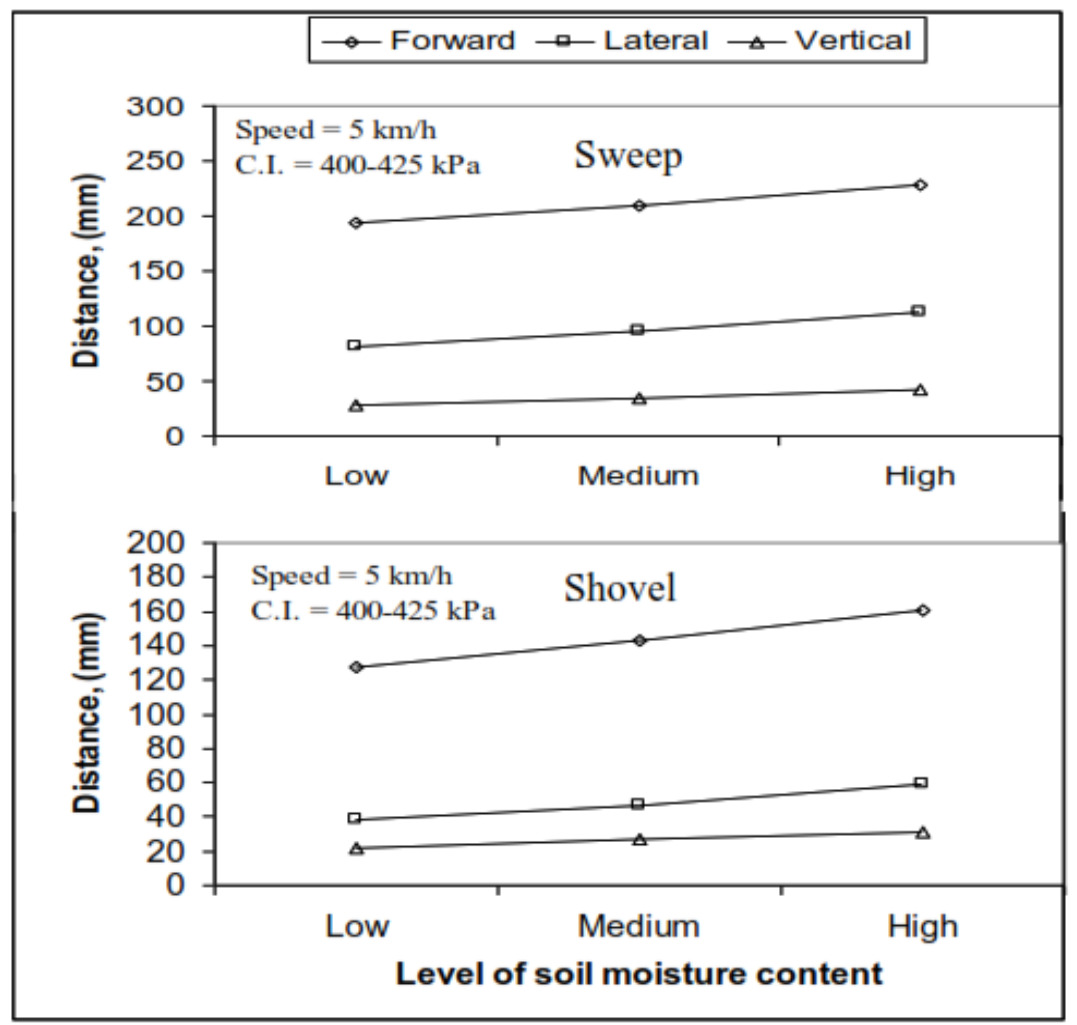

Figure (7): The average distance of plastic blocks movements in three directions at different levels of soil moisture using sweep and shovel shares.

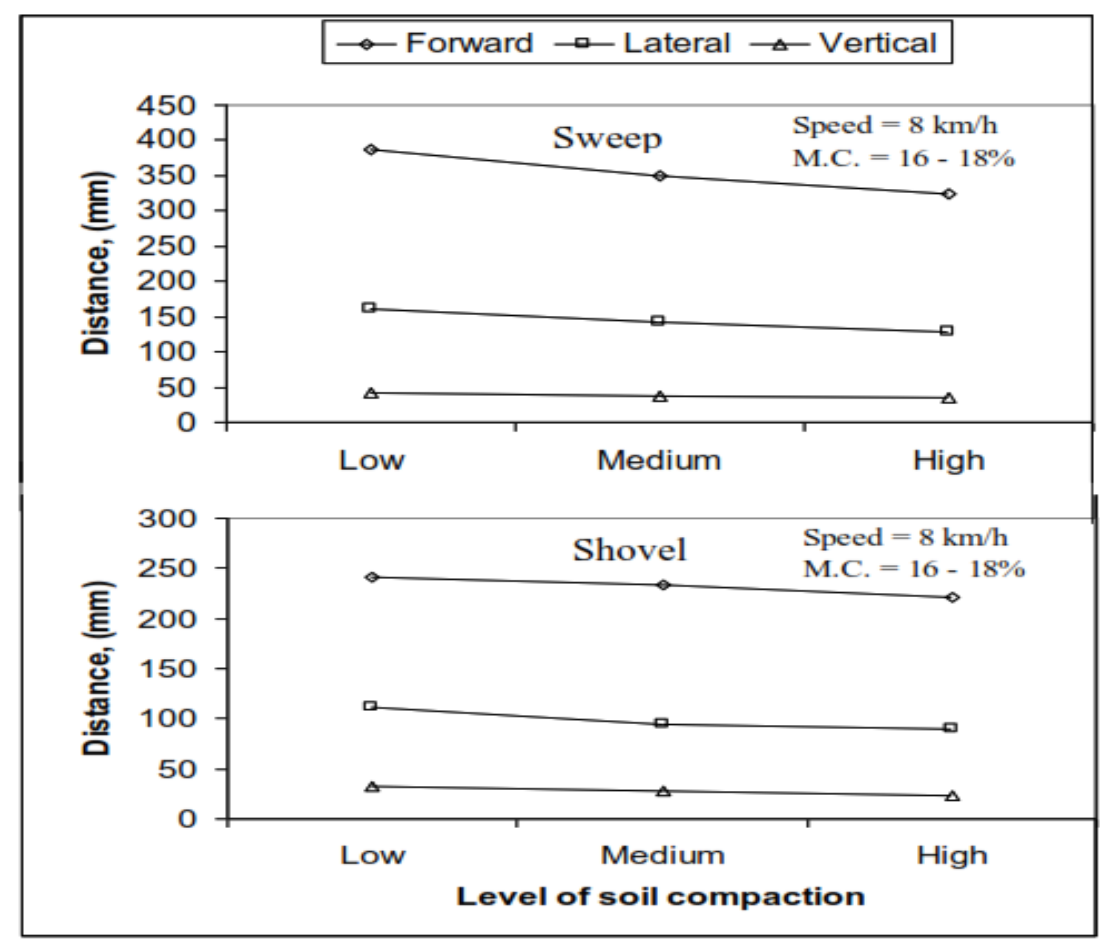

Figure (8): The average distance of plastic blocks movements in three directions at different levels of soil compaction using sweep and shovel shares.

\subsection{Soil movement at different depths of block layer}

Drawing the graphs of soil movement with respect to depth for different layers of soil as simulated by the block layers under different conditions of this study showed that, the relation 
between soil movement with depth approximately takes an exponential function for both the shovel and the sweep shares. Figure 9 shows the forward soil movement by sweep share at soil conditions of high moisture content, high soil compaction and at $8 \mathrm{~km} / \mathrm{h}$ tool speed, respectively. It can be noticed that, the forward soil movement decreased as the depth of block layers increased for the two shares. However, the sweep share resulted in the higher values of the forward soil movement compared with that for shovel at different depths of block layers. Similar trend of lateral and vertical soil movements versus depth of block layers were obtained at different soil moistures, soil compaction and at different speeds. At $90 \mathrm{~mm}$ (depth of tool operation), the soil particles coming in contact with tool will share and move a distance shown in Figure 9 which marked by the arrow. However, the particles just beneath this operating depth will tend to move, but will remain partially displaced (Sharifat and Kushwaha, 1997).

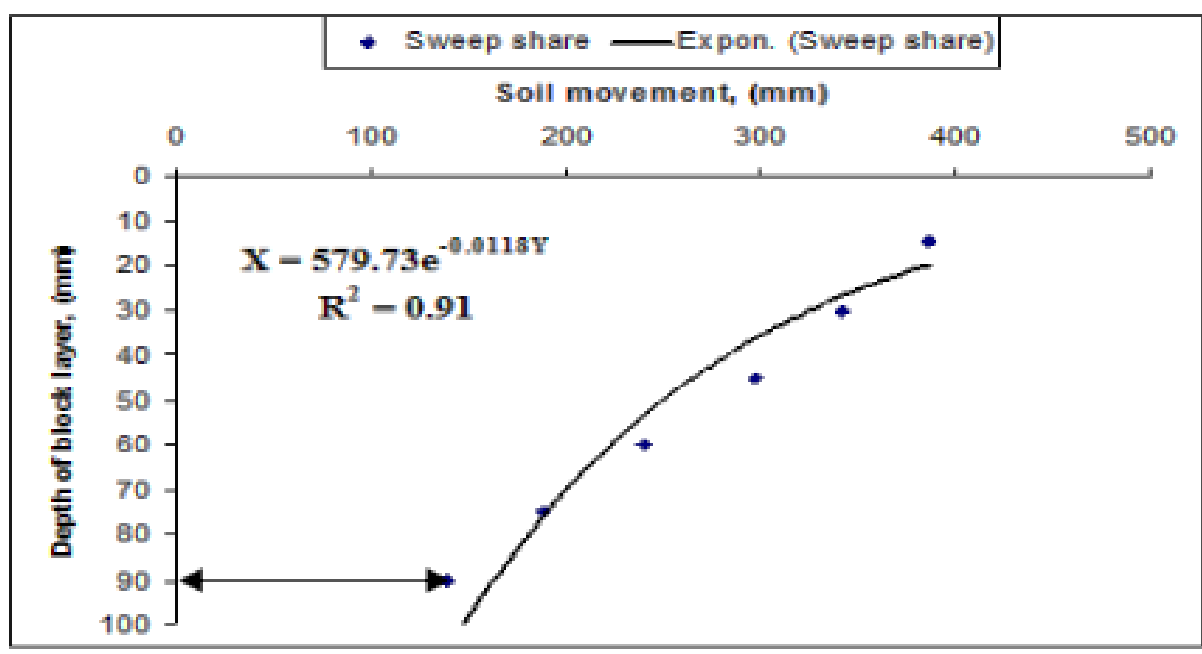

Figure (9): Forward soil movement at different depths of block layer using sweep share.

\subsection{Statistical Analysis}

Regression analysis was performed using the MINITAB statistical package to derive a mathematical relation between the soil movements in three directions with respect to soil moisture content, soil compaction, and tool speed for the two shares used. Under experimental conditions of this study, the derived equations are:

For the sweep share

$$
\begin{array}{ll}
F=139+38.2 M-54 C+91 S & \left(\mathrm{R}^{2}=0.95\right) \\
L=49.3+20.4 M-22.4 C+38.3 S & \left(\mathrm{R}^{2}=0.93\right) \\
V=13+10.2 M-8.09 C+14.6 S & \left(\mathrm{R}^{2}=0.92\right)
\end{array}
$$

For the shovel share

$$
\begin{array}{ll}
F=72.7+23.3 M-15.3 C+36.5 S & \left(\mathrm{R}^{2}=0.98\right) \\
L=38.8+12 M-12.6 C+10.9 S & \left(\mathrm{R}^{2}=0.92\right) \\
V=37+6.13 M-10.3 C+3.41 S & \left(\mathrm{R}^{2}=0.90\right)
\end{array}
$$

Where:

$\mathrm{F}=$ forward soil movement, $(\mathrm{mm}), \mathrm{L}=$ lateral soil movement, $(\mathrm{mm}), \mathrm{V}=$ vertical soil movement, $(\mathrm{mm}), \mathrm{M}=$ soil moisture content, $(\%), \mathrm{C}=$ soil compaction, $(\mathrm{kPa})$, and $\mathrm{S}=$ tool speed, $(\mathrm{km} / \mathrm{h})$. 
Also, analysis of variance was performed for the soil movements in three directions in relation to soil moisture, soil compaction, and the tool speed for the two shares used. Results of this analysis are shown in Table (1).

Table 1: Analysis of variance results for all data under this study

\begin{tabular}{|c|c|c|c|c|c|c|c|}
\hline \multirow[t]{2}{*}{ Source } & \multirow[t]{2}{*}{$\mathrm{DF}$} & \multicolumn{2}{|c|}{$\begin{array}{l}\text { Forward } \\
\text { movement }\end{array}$} & \multicolumn{2}{|c|}{$\begin{array}{l}\text { Lateral } \\
\text { movement }\end{array}$} & \multicolumn{2}{|c|}{$\begin{array}{l}\text { Vertical } \\
\text { movement }\end{array}$} \\
\hline & & F value & $\mathrm{P}$ & F value & $\mathrm{P}$ & F value & $\mathrm{P}$ \\
\hline T (Tool) & 1 & $4.0 \mathrm{E}+06$ & $0.000^{*}$ & $1.9 \mathrm{E}+06$ & $0.000 *$ & $4.9 \mathrm{E}+04$ & $0.000^{*}$ \\
\hline M (Moisture) & 2 & $3.1 \mathrm{E}+05$ & $0.000^{*}$ & $1.7 \mathrm{E}+05$ & $0.000 *$ & $3.7 \mathrm{E}+04$ & $0.000 *$ \\
\hline C (Compaction) & 2 & $4.0 \mathrm{E}+05$ & $0.000^{*}$ & $2.1 \mathrm{E}+05$ & $0.000 *$ & $4.8 \mathrm{E}+04$ & $0.000 *$ \\
\hline S (Speed) & 2 & $1.4 \mathrm{E}+06$ & $0.000^{*}$ & $4.0 \mathrm{E}+05$ & $0.000 *$ & $4.6 \mathrm{E}+04$ & $0.000 *$ \\
\hline R (Replicates) & 2 & 285.56 & $0.000^{*}$ & $1.1 \mathrm{E}+04$ & $0.000^{*}$ & 2237.43 & $0.000^{*}$ \\
\hline $\mathrm{T} * \mathrm{M}$ & 2 & $2.3 \mathrm{E}+04$ & $0.000^{*}$ & $1.2 \mathrm{E}+04$ & $0.000 *$ & 2268.42 & $0.000 *$ \\
\hline $\mathrm{T} * \mathrm{C}$ & 2 & $1.2 \mathrm{E}+05$ & $0.000^{*}$ & $1.7 \mathrm{E}+04$ & $0.000 *$ & 1005.36 & $0.000 *$ \\
\hline $\mathrm{T} * \mathrm{~S}$ & 2 & $2.6 \mathrm{E}+05$ & $0.000^{*}$ & $1.3 \mathrm{E}+05$ & $0.000^{*}$ & $1.8 \mathrm{E}+04$ & $0.000^{*}$ \\
\hline $\mathrm{T} * \mathrm{R}$ & 2 & 6919.55 & $0.000^{*}$ & 3405.38 & $0.000 *$ & 2637.36 & $0.000 *$ \\
\hline $\mathrm{M} * \mathrm{C}$ & 4 & 2502.12 & $0.000^{*}$ & 2312.82 & $0.000 *$ & 595.92 & $0.000 *$ \\
\hline $\mathrm{M} * \mathrm{~S}$ & 4 & 8311.70 & $0.000^{*}$ & 4298.43 & $0.000^{*}$ & 678.27 & $0.000 *$ \\
\hline $\mathrm{M} * \mathrm{R}$ & 4 & 2.23 & 0.087 & 121.87 & $0.000 *$ & 30.75 & $0.000 *$ \\
\hline $\mathrm{C} * \mathrm{~S}$ & 4 & $1.2 \mathrm{E}+04$ & $0.000^{*}$ & 5127.33 & $0.000 *$ & 597.15 & $0.000 *$ \\
\hline $\mathrm{C}^{*} \mathrm{R}$ & 4 & 7.81 & $0.000^{*}$ & 129.16 & $0.000^{*}$ & 35.45 & $0.000^{*}$ \\
\hline $\mathrm{S} * \mathrm{R}$ & 4 & 25.95 & $0.000^{*}$ & 242.09 & $0.000 *$ & 44.39 & $0.000 *$ \\
\hline $\mathrm{T} * \mathrm{M} * \mathrm{C}$ & 4 & 750.20 & $0.000^{*}$ & 88.00 & $0.000 *$ & 3.29 & 0.023 \\
\hline $\mathrm{T} * \mathrm{M} * \mathrm{~S}$ & 4 & 1542.54 & $0.000^{*}$ & 1046.54 & $0.000^{*}$ & 313.98 & $0.000 *$ \\
\hline $\mathrm{T} * \mathrm{M} * \mathrm{R}$ & 4 & 43.66 & $0.000^{*}$ & 29.23 & $0.000 *$ & 46.49 & $0.000 *$ \\
\hline $\mathrm{T}^{*} \mathrm{C} * \mathrm{~S}$ & 4 & 5205.30 & $0.000^{*}$ & 1352.82 & $0.000 *$ & 132.89 & $0.000 *$ \\
\hline $\mathrm{T}^{*} \mathrm{C}^{*} \mathrm{R}$ & 4 & 56.56 & $0.000^{*}$ & 53.57 & $0.000^{*}$ & 49.51 & $0.000^{*}$ \\
\hline $\mathrm{T} * \mathrm{~S} * \mathrm{R}$ & 4 & 178.59 & $0.000^{*}$ & 120.52 & $0.000 *$ & 49.60 & $0.000 *$ \\
\hline $\mathrm{M} * \mathrm{C} * \mathrm{~S}$ & 8 & 72.38 & $0.000^{*}$ & 53.96 & $0.000 *$ & 5.66 & $0.000 *$ \\
\hline $\mathrm{M} * \mathrm{C} * \mathrm{R}$ & 8 & 0.57 & 0.792 & 2.26 & 0.048 & 1.05 & 0.420 \\
\hline $\mathrm{M} * \mathrm{~S} * \mathrm{R}$ & 8 & 0.29 & 0.964 & 1.81 & 0.111 & 1.80 & 0.113 \\
\hline C*S*R & 8 & 1.47 & 0.205 & 8.60 & $0.000 *$ & 2.27 & 0.047 \\
\hline $\mathrm{T} * \mathrm{M} * \mathrm{C} * \mathrm{~S}$ & 8 & 31.55 & $0.000^{*}$ & 11.35 & $0.000 *$ & 3.44 & $0.006^{*}$ \\
\hline $\mathrm{T} * \mathrm{M} * \mathrm{C} * \mathrm{R}$ & 8 & 0.99 & 0.465 & 0.36 & 0.936 & 1.65 & 0.151 \\
\hline $\mathrm{M} * \mathrm{C} * \mathrm{~S} * \mathrm{R}$ & 16 & 0.40 & 0.971 & 0.38 & 0.977 & 0.56 & 0.892 \\
\hline Error & 32 & & & & & & \\
\hline Total & 161 & & & & & & \\
\hline
\end{tabular}

*Highly significant at $\mathrm{P} \leq 0.01$.

\section{CONCLUSION}

This study was carried out to investigate the effect of soil conditions and operational parameters of plowing on soil erosion using two common shares of chisel plow in Egypt. The obtained results cleared that:

- The soil movement increase in the case of using sweep share compared to shovel one under different operational factors.

- The increase in the operational speed caused an increase in both lateral and vertical movements and resulted in a decrease in the forward one.

- Increasing soil moisture content from low level to high level resulted in about $15 \%$ and $21 \%$ increase in the forward movement of the plastic blocks for the sweep and shovel shares, respectively.

- Statistical analysis indicated that there was highly significant difference in soil movements in three directions. 
- From the obtained results, it can be concluded that the rate of soil erosion can be reduced in the case of using shovel share instead of sweep one under the conditions of low speed and low moisture content.

\section{REFERENCES}

ASAE Standards (1990). S313.2. Soil Penetrometer. $37^{\text {th }}$ Ed. St. Joseph, MI:ASAE, pp. 820821

ASTM (1991). Standard D2216-90. Methods for laboratory determination of moisture content of soil. In Annual Book of ASTM Standards. 0408: 278-281. Philadelphia, PA: American Society for Testing and Materials.

Abd El-Wahab, M.K. (1994). Minimum tillage by a simple combination. Misr Journal of Agricultural Engineering, 11(1):711-724.

Chase, L. W. (1942). A study of subsurface tiller blades. Agricultural Engineering 23:43-45, 50 .

Dowell, F.E., Siemens J.C. and Bode L. E. (1988). Cultivator speed and sweep spacing effects on herbicide incorporation. Transactions of the ASAE 31(5):1315-1321.

Eidet, J. H. (1974). Effect of varied approach angle on high speed mouldboard plow performance. Unpublished M.Sc. thesis. Iowa State University, Ames, IA.

Ellison, W. D. (1947). Soil erosion studies- Part II. Agricultural Engineering 28:197-201.

Goryachkin, V. P. (1968). Collected works in three volumes. Ed. N. D. Luchinskii. Translated 1972. Jerusalem, Israel: Ketter Press.

Hanna, H.M., Erbach D.C., Marley S.J. and Melnin S.W. (1993a). Comparison of the Goryachkin theory to soil flow on a sweep. Transactions of ASAE 36(2):293-299.

Hanna, H.M., Erbach D.C., Marley S.J. and Melnin S.W. (1993b). Changes in soil microtopography by tillage with a sweep. Transactions of ASAE. 36(2): 301-307.

Lobb, D. A. and Kachanoski R. G. (1997). Quantification of tillage translocation and tillage erosion. Presented at the tillage translocation and tillage erosion: An International Symposium, Part of the $52^{\text {nd }}$ Annual Conference of the Soil and Water Conservation Society, Toronto, ON, Canada, pp. 189-209

Pimentel, D. (1993). World soil erosion and conservation. Cambridge, NY: Cambridge University Press.

Sharifat, K. and Kushwaha R. L. (1997). Soil translocation by two tillage tools. Canadian Agricultural Engineering 39(2):77-84.

Sibbesen, E., and Anderson C. E. (1985). Soil movement in long-term experiments as a result of cultivations: II. How to estimate the two-dimentional movement of substances accumulating in the soil. Journal of Experimental Agriculture. (21): 109-117.

Söhne, W. (1960). Suiting the plow body shape to higher speeds. National Institute of Agricultural Engineering Translation No. 101(12):51-62.

Turkelboom, F., Poesen J., Ohler I., Van Keer K., Ongprasert S. and Vlassak K. (1996). Assessment of tillage erosion rates on steep slopes in northern Thailand. Catena 29: 29-44. 
حركة التربة لنوعين من أسلحة المحراث الحفار الثائعة الاستخدام في مصر محمد تهامي عفيفي'

'مدرس بقسم هندسة النظم الزر اعية و الحيوية ـ كلية الزر اعة ـ جامعة بنها ـ مصر.

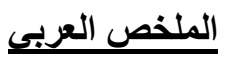

إذا كانت حركة حبييات التربة أثناء عملية الحراثة هي رد فعل للقوة التي تؤثر بها معدات الحر اثة على التربة وتتسبب في إحداث قص وتفكيك ونقل لحبيبات التربة كما تقوم بتحريكها في عدة اتجاهات، فإن هناك جزءا كبير ا من هذه الحركة أثناء عملية الحر اثة ليس فقط غير ولير

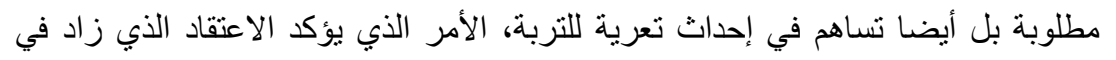

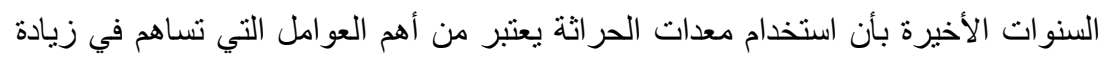
تعرية التربة والتي يظهر أثرها في خفض إنتاجية المحاصيل عن طريق تقليلها لاحتفاظ التربة

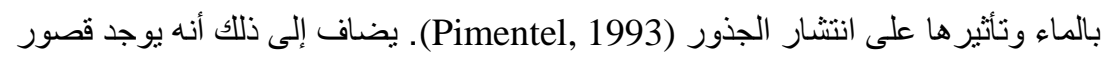

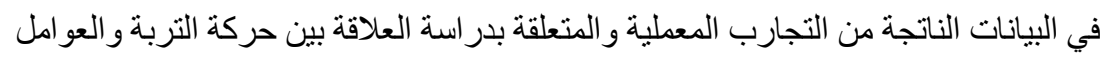

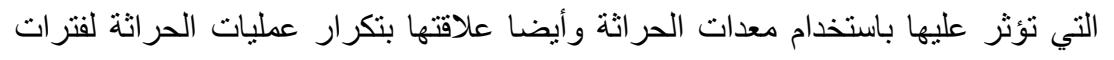
زمنية طويلة (Sharifat and Kushwaha, 1997). لذلك فإن الهدف من هذا البحث هو در اسة تأثثر كل من ظروف التربة و وعو امل تشغيل المعدة على حركة التربة باستخدام نوعين

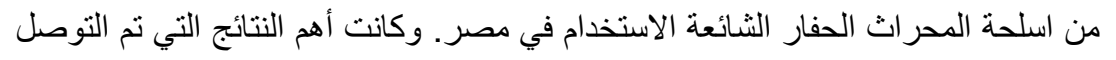

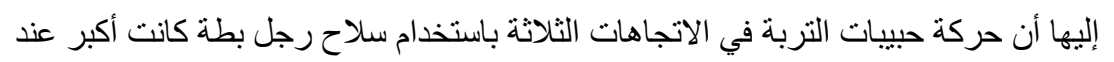

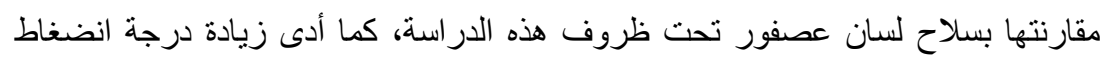
التربة إلى نقص في متوسط الحركة الأمامية لحبيبات التربة لكلا السلاحين. لذا وطبقا لنتائج هذا البحث يمكن التوصية بأن استخدام سلاح لسان عصفور في نفس العمل الذي يستخدم فيه

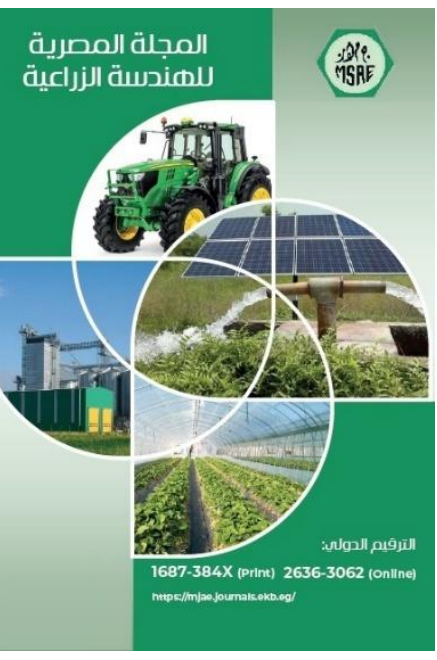

C) (المجلة المصرية للهندة الزراعية

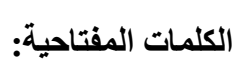
حركة التربة، المحر اث الحفار ، طريقة التتابع، انضغاط التربة التزه، سلاح رجل بطة سوف يؤدي إلى تقليل التعرية للتربة. 